\title{
Minutes of the April 13, 2013, APSA Council Meeting
}

\section{PLACE AND ATTENDANCE}

Palmer House Hotel, Chicago, IL

Present: Jane Mansridge, John $\mathrm{H}$. Aldrich, Nancy J. Hirschmann, AnneMarie Slaughter, Jonathan BenjaminAlvarado, John C. Green, Brian Crisp, Juan Carlos-Huerta, Joanne Miller, Todd C. Shaw, Kenneth D. Wald, Paul Gronke, Ange-Marie Hancock, David A. Lake, Taeku Lee, Kenneth J. Meier, Kathleen Thelen, Stephen M. Walt, Angelia R. Wilson, John Ishiyama, Jeffrey Isaac, Catherine Boone, and Michael Brintnall.

APSA Staff Present: Regina Chavis, Polly Karpowicz, Jennifer Diascro, Betsy Super, Barbara Walthall, Jeff Biggs, Jonathan Gilad, and Kim Mealy.

Guests: Rodney Hero and Melanie Manion

\section{CALL TO ORDER}

The regular meeting of the APSA Council on Saturday, April 13, 2013, was called to order at 8:30 a.m. by President Mansbridge.

\section{WELCOME AND REPORT OF THE PRESIDENT}

President Jane Mansbridge opened proceedings and asked for each council member and APSA staff to introduce themselves. She then introduced Rodney Hero, the nominee for president-elect for 2013-2014.

President Mansbridge reported that APSA is a very healthy organization. She mentioned how she recently attended the Teaching and Learning Conference, an event with a wonderfully powerful sense of people doing things and who were excited about what they were doing.

On the executive director search, she affirmed that Steven Rathgeb Smith had accepted the offer made. She and Steve had recorded video announcements and they would be made public shortly.

Mansbridge also updated several other on-going activities noting that her Task Force on Negotiating Agreement in Politics was proceeding well and on schedule. She affirmed she is also con- tinuing the work of past APSA Presidents Dianne Pinderhughes and Carole Pateman in addressing matters of diversity and of women in the profession. She will have a report at the August meeting on advancing senior women in the profession and at this conference has met e with a working group focused on advancing scholars of color particularly in the tenure process, including building better systems of data collection.

\section{COUNCIL ORIENTATION}

Michael Brintnall provided a background report on council responsibilities and roles, as an orientation for the new council members. He highlighted that the council is the governing board of directors of the association, accountable to the membership. He noted the difference between playing a leadership role in the discipline and governance role in the association, and recognized that the council is often asked to do both. Brintnall reviewed council member responsibilities, APSA structure, financial administration, governing documents, and the fundamental duties of a governing board member: duty of care, duty of loyalty, and duty of obedience.

\section{CONSENT AGENDA}

President Mansbridge then brought council attention to the minutes from the previous council meeting. There were no issues for discussion. Mansbridge asked for a motion to accept the minutes, which were approved via voice vote.

\section{REPORT OF THE EXECUTIVE DIRECTOR}

Michael Brintnall presented his report in which he noted that the association is weathering the many challenges in front of us well, and is strong. Staffing is stable and positive. The building at $1527 \mathrm{New}$ Hampshire Avenue is newly renovated and back in one piece.

He acknowledged the variety of issues highlighted in the executive director's report, including RBSI, the Hanes
Walton. Jr. fund, the Beryl Radin Fund, and the IPSA executive committee meeting at APSA headquarters in May. $\mathrm{He}$ added that there are two system issues getting attention: one is a need to manage financial relations with the organized sections, in new ways-carrying their assets directly on the APSA books, following guidance from new auditors; the other is replacing the association management system, our major database; action on both issues is moving forward.

Finally, Dr. Brintnall noted that this is the international year of statistics, and asked for council endorsement to support this event. There was no objection.

President Mansbridge reminded the council that Michael Brintnall will be retiring and thanked him for his years of service and commitment to APSA and joined the council in congratulations.

\section{FINANCE REPORT}

Regina Chavis, APSA Director of Finance and Administration, presented the finance report. She noted the Teaching and Learning Conference operates at a deficit but they were able to bring the amount of deficit down. The audit report was again clean this year. It was a more intense process than usual with the new auditors who came in, which was very useful. Regina Chavis answered questions from council members Todd Shaw and Ken Wald regarding the new auditor and website revenue, referenced on pp. 12-14, respectively. David Lake asked about the appearance that publications operate at a deficit. Dr. Brintnall noted that the reports just show Cambridge University Press revenues (i.e., the institutional or library revenues), and not a share of member revenue related to publishing.

It was noted that the cancellation of the APSA Annual Meeting in New Orleans had not resulted in financial loss. Insurance covered losses, and APSA has completed returning registration fees to members.

Dr. Jonathan Benjamin-Alvarado thanked Chavis for easy-to-read-and- 
understand financial reports; commended the staff for work in stewarding the association finances. The association is in good standing and in a secure position.

\section{ANNUAL MEETING UPDATE}

Dr. Catherine Boone (Annual Meeting Program Co-Chair) gave the council an update on preparations for the 2013 Annual Meeting in Chicago. The theme is similar to President Mansbridge's work on her Task Force and they are looking to see how these themes can be further spread across the discipline.

Boone said there are currently 30 theme panels (12 program-chair developed, others from division chairs), and special panels on the National Science Foundation (NSF) funding, women in the profession, voter suppression, power and pundits, and lessons of war from Iraq. Boone also mentioned that the presidential address will be earlier on Thursday (6 p.m.) to allow members to attend before they go to dinner. The Opening Reception will be later at night.

The council asked about an update with the labor situation. Brintnall explained that the Hyatt Hotel was still in a protracted labor dispute and could not give assurances that this would be settled by the time we needed to commit to the site (the dates proposals are due). The Hyatt voluntarily agreed to let APSA out of the contract. Brintnall said that the Hyatt acted in a manner consistent with contract language permitting us to move in the face of labor disputes, but that this this action did not represent an actual legal test of the contract language, since the Hyatt responded voluntarily. APSA has booked the meeting at two Chicago hotels instead: Hilton and Palmer House (also a Hilton hotel). We have retained our original agreement with the Sheraton Hotel, since they were in compliance with our expectations about labor. There will be spill over hotel space available there at a slightly reduced rate, and we have booked some special activities, such as the Mini Workshop on Women of Color, but overall we have regrettably needed to cut back on the amount of business scheduled there.

Brintnall summarized the panel allocation issues raised by the Section on Migration and Citizenship, which were that the number of submissions for this new division were far higher than the numbers that were used to allocate panels as a related group, and thus the baseline allocation of panels is much less than actual demand for this meeting. The Section had asked that current proposal submissions be used this year to increase its allocation, among other things.

Brintnall responded that it could be workable for the future to use currentyear submission data-rather than prior year submission. He noted that allocations are granted by a well-vetted procedure and not done idiosyncratically by the staff or program chairs; and that any change should be discussed widely.

\section{ANNUAL MEETING}

President-elect John Aldrich introduced the program co-chairs for the 2014 Annual Meeting: Melanie Manion and Simon Jackman. Dr. Manion distributed a draft theme statement. "Politics after the Digital Revolution." She said the theme lends itself to being inclusive of discipline as a whole and to the chairs individually and to each subfield and area of research and feels this will change the way political scientists communicate among themselves.

The council discussed the idea of looking into a smartphone app for this annual meeting program, to not have a paper conference program, and to only provide a paper program for those who 'opt in' for one. Brintnall said that the APSA staff will look into this issue and report back to the council, with an eye to starting the service in 2013.

\section{G. BINGHAM POWELL'S TASK FORCE}

The council was provided with the draft table of contents and first chapter of the final report of the APSA 12-member Task Force on Electoral Rules and Democratic Governance.

The Council received the report from the Task Force.

\section{INTERNATIONAL INITIATIVES}

Betsy Super, APSA Director of International Initiatives, reviewed the multiyear Andrew W. Mellon Foundation's support of the Africa Workshop program focused on political science research and teaching in Sub-Saharan Africa. Dr. Super went on to discuss ongoing plans for the 2013 Middle East and North Africa workshop. The council was very enthusiastic about APSA international involvement.
DATA ACCESS AND RESEARCH TRANSPARENCY (DART)

On behalf of the APSA Ethics Committee, Dr. Super noted the adoption of updated language on "Principles for Researchers" in the APSA Guide to Professional Ethics in Political Science. The Ad Hoc Committee on Data Access and Research Transparency continues to oversee research-specific guidance to help scholars, journals, funding agencies, and others on best practices. She pointed out that research transparency is not a "one-size-fits all" proposition, and drafts of separate guidelines for data access and research transparency in the qualitative and quantitative research traditions are being finalized and readied for circulation and feedback. These are expected to recognize privacy and confidentiality concerns.

Activities undertaken and/or planned include: a DART short course conducted at the March 2013 Western Political Science Association Meeting; roundtables of proponents of the transparency project and editors of important political science journals at the MPSA and APSA Annual Meeting; a new module on "Managing and Sharing Data" added to the curriculum of the Institute for Qualitative and Multimethod Research (IQMR) to be presented in June 2013; a short course planned for the 2013 APSA meeting to include introduction of and instruction on DA-RT; a September 2013 University of Virginia conference on "History, Method, and the Future of Security Studies" with one session focusing on transparency practices; and a symposium on DART scheduled for submission for the January 2014 issue of PS: Political Science and Politics.

\section{AMERICAN POLITICAL SCIENCE REVIEW INTRODUCTIONS}

Dr. John Ishyama, Editor of American Political Science Review (APSR), introduced his editorial team. He also acknowledged a postdoc and other staff members who could not attend the council meeting.

\section{PERSPECTIVES ON POLITICS EDITOR'S REPORT}

Perspectives on Politics Editor Dr. Jeff Isaac introduced some of his staff and thanked them for all their hard work. He mentioned how the editorial board is growing and thanked the council for earlier approvals of new members. He said Perspectives is committed to fostering 
a journal of public sphere and doing so without having a large backlog. Isaac mentioned they are filled through next year's March issue and many of the submissions are from junior scholars.

The council then discussed Perspectives and how it can be more helpful with its challenges in the future. Isaac mentioned how the journal tries to stay on target and his staff was proud of the New Orleans special issue because of its relevance and issuance during the 2012 Annual Meeting. The council agreed that that the effect of this work was not lost in spite of the meeting cancellation and it was hugely important.

The council asked Isaac if he foresaw any future problems and ways to address them. Dr. Isaac said that his main concern was "rejection letters" and timeliness with reviews. He is using the expanded editorial board to help with this. Isaac mentioned how he helped authors who have been rejected identify ways to improve their research so that they may get published in the future. As for the expansion, Isaac said he is looking for scholars who are energetic and can take the journal forward. Procedurally, nominations will come before the council.

Dr. Gronke asked about turnaround time on book reviews. Some books seem to take a very long time for them to be reviewed. Dr. Isaac explained that this is a logistical challenge but they are committed to reviews and writing quality. For some books there are problems with finding reviewers, and others there were formatting delays that lead to its late review. Sometimes they decide not to review a book because too much time has already lapsed.

Dr. Isaac then referenced page 87 in the council book regarding the Membership Communications Ad Hoc Committee proposal. Specifically that $P S$ was mentioned as a public engagement venue but not Perspectives, which Isaac considers it to be. Perspectives was also not mentioned along with APSR as a scholarly journal, which gives him the impression that Perspectives is "caught between a rock and a hard place to be relevant and scholarly."

\section{PS: POLITICAL SCIENCE AND POLITICS EDITOR'S REPORT}

Rob Hauck, Editor of $P S$, said a few words about $P S$. He mentioned how it has been publishing since 1968 with a staff of two, and prints annually 1,200 pages.
Hauck reported that $P S$ has updated the editorial manager system, which is helpful in finding an adequate number of reviewers. $P S$ is host to a growing number of symposia and an increasingly longer list of people who want to propose symposia. Currently they are working on defining mission vis-à-vis Perspectives on Politics and that is one of the boards top priorities. He finished by thanking Barbara Walthall and Michael Marvin who helped push PS out front in marketing. Hauck said that were would be more in his report at the next council meeting.

\section{PUBLICATIONS PLANNING COMMITTEE}

Dr. Jennifer Hochschild delivered the report from the Publications Planning Committee. She started by outlining the charge of the committee which was to thread through ongoing activities throughout APSA related to publications, broadly defined. The committee's goal is to step back to evaluate underlying principles, identify audiences, and finally find the strengths/weaknesses of APSA journals and other outlets and forums for scholarly production and exchange. Hochschild said that the idea is to think through logic and principles and frameworks for developing existing publications or new publications. She said that the committee membership was composed of great disciplinary diversity.

Hochschild said the committee has four working groups focusing predominantly on research, teaching, public engagement, and professional development. Each group has been asked to think about four values relevant to publication: (1) entrance: opportunities to publish; (2) discovery: access to scholarship; (3) breadth: shared engagement in communication (4) quality: peer review and other ways of thinking about quality of publications. They are also addressing several significant issues such as open access; registry; multiple formats for publication; identifying the role for APSA; enhancing public outreach; and a possible change in peer review. Hochschild also mentioned that the electronic journal proposal is not on their agenda per se, although they hope to provide a framework in which the publications committee and council could evaluate that or other new proposals.

In response to other questions, she said the committee is widely focused on a variety of stakeholders in the publications process, including graduate students and young faculty focused on professional advancement and tenure, on journal editors facing pressures to find reviewers and to address reviewer fatigue, and on policy makers and scholars in the policy process. Others asked about overlaps among this committee and other planning groups, such as member communications, and the proposed public engagement Task Force. Hochschild said those relationships are not clear. Others urged the committee to explore the publication rates of women, minorities, and junior faculty.

President-elect Aldrich responded that as the committee develops over the summer, they will have a have report that can specify and move forward a variety of issues, and that can then be aligned with the work of other committees. The council thanked Hochschild and the committee for their ongoing work.

\section{ADVOCACY UPDATE}

Dr. Jennifer Diascro, APSA Director of Institutional Programs, introduced APSA staff member Jonathan Gilad and then presented the council with a slide show outlining the APSA's advocacy efforts.

The slides outlined the various ways APSA hopes to engage Congress in the near and long term. Near-term efforts focus on finding ways to mobilize support around elimination of the so-called Coburn amendment that restricts political science funding at the NSF.

For the long-term efforts, APSA will work to make political science a more sustained presence on Capitol Hill, including Hill events, presenting at the CNSF exhibition, conduct advocacy days, and Hill professional seminars. Furthermore, she proposed some new engagement with membership by encouraging members to write op-ed letters in local newspapers, hold district visits, and a host a panel at the Annual Meeting. She also outlined the various partners APSA has in its advocacy efforts. In terms of messaging, Diascro outlined that the association is concentrating on defending the scientific process as a first priority, with attention to consequential individual studies secondarily. Diascro also mentioned that it is important to find political conservatives to stand up and defend political science as well.

The council discussed at length the issue regarding the Coburn amendment and the overall political atmosphere 
regarding political science. Several members offered suggestions of people to contact but agreed with the overall sentiment of the presentation and its messaging, and acted to authorize APSA to seek professional lobbying support. President Mansbridge entertained a motion: "... to approve the spending of $\$ 20$,ooo to hire a lobbyist to assist with our advocacy efforts." The council approved the motion unanimously.

\section{RALPH BUNCHE SUMMER} INSTITUTE FUNDING

Dr. Kimberly Mealy briefed the council on the funding for the 2013 RBSI summer program that had been cancelled. Mealy discussed how the proposal was caught up in the Coburn amendment-the NSF political science program had signaled it would support the 2013 program, but had not committed funds because of questions about sequestration, and when the Coburn restrictions emerged, the program was then unable to commit any funds. At this stage, Duke University could not long hold the program open and applicants needed to have the opportunity to make other summer plans. Applicants were notified immediately of the cancellation. Professors and graduate assistants were already told of the cancellation and therefore Duke (believed there was no chance for a program this summer) released the space. Therefore Duke would not be able to host the program this year. Professor Aldrich said that Duke University is a committed partner for this project, but that a secure line of funding is important.

Currently Dr. Mealy is working on a series of RBSI-like programs instead at the 2013 Annual Meeting activities. Dr. Mealy said that she would provide a concrete plan and asked the council for advice.

Dr. Mealy also discussed the development concerns for the RBSI, for the 2014 funding, and said that APSA staff is working with an advisory committee of alumni to come up with a plan. Dr. Jonathan Benjamin-Alvarado said that the RBSI is vital to recruit and retain graduate students. It is important that we retain this instrument to continue this for people of color/minorities. It would be a shame to lose this program. Dr. Slaughter asked if the website will post all the public data and statistics on the program so that council members can use them when addressing their colleagues.
The council continued discussing the issue and agreed that the RBSI program is important and should not be lost. The council then began discussing fundraising options for the program, including the prospect of seeking to build an endowment of about $\$ 3$ million. This is a fundraising goal that APSA has never been achieved previously. President Mansbridge explained that the development committee has to meet and the council still has to discuss the Hanes Walton Fund, although she would like to find a way to raise money for both as soon as possible. There was discussion of whether to place a surcharge on dues to raise funds for the RBSI. President Mansbridge said that she preferred donations rather than an increase in dues.

Dr. Brintnall responded that we can conduct a modified summer program this year and will work on a plan for next year with a commitment to find funds for the RBSI.

\section{HANES WALTON, JR. FUND}

Dr. Brintnall discussed the issues surrounding a proposal to honor the memory of Hanes Walton, Jr.-with either a new book award for work on racial politics or another fund. The idea of a book award appears to duplicate the Ralph Bunche Book Award, and the development committee has suggested a fund be set up instead under Centennial Center funds to support new scholarship on racial and ethnic politics.

President Mansbridge responded that currently the motion is for passage of the fund or against, therefore there was no flexibility. Dr. Lee asked if the development committee had consulted with scholars who worked with Hanes Walton, Jr., and Dr. Brintnall responded that they had, and that some disagreement remained about having a Centennial Center fund rather than an award.

The motion for establishing the Hanes Walton, Jr. Centennial Programs Fund was accepted unanimously by the council.

\section{JOHN ALDRICH TASK FORCE ON PUBLIC ENGAGEMENT}

President-elect John Aldrich outlined his task force topic. He explained that the origins of the topic lay in Henry Brady's earlier Ad Hoc Committee on Public Understanding of Political Science.

The council discussed the Task Force topic as well as its composition. Skip
Lupia was widely supported to chair, and the council had additional suggestions for names of scholars to participate. President-elect Aldrich assured the council that he would take into consideration all the names that were mentioned

Other points were raised, including the degree of coordination between the Task Force and the Publications Committee, whether the proposal is beginning with a premise-that we should model ourselves after psychology and economics-that is problematic; whether a "readable journal" will be part of the larger conversation of this or other planning committees, and how this will coordinate with the other planning committees.

The council voted unanimously to approve the Task Force topic, and to hear back from the president-elect about proposed membership.

\section{RULES COMMITTEE REPORT}

Dr. David Lake, chair of the Rules Committee, reported on APSA governance reform. The Rules Committee has been asked to look into how governance planning might take place. They suggest that the president appoint an ad hoc committee that represents many dimensions of the association and has experience with institutional structures of APSA to look into ideas for change. The committee process should include a retreat of committee members to discuss reform. At the retreat, the committee would draft (with input) a list of recommendations for the APSA Constitution and governance reform that will then go to the membership for further comment. After the revision, the proposal will go to the full membership for a vote. He expects this process would last about three years.

Lake said the Rules Committee was not recommending any particular approach now, and would provide a report at the August meeting suggesting a plan to go forward to putting a review committee together.

\section{MEMBERSHIP COMMUNICATIONS AD HOC COMMITTEE}

Dr. Brintnall introduced the report on the ad hoc membership communications committee-which is meant to help membership concerns with communication questions. He noted that an immediate action is to update to the APSA homepage layer, as a first step toward redeveloping the website. The 
goal is to re-craft the APSA homepage to be more supportive of the needs of the association and various constituents and to demonstrate that APSA is the central resource in the profession. He noted that the association is facing several major technology upgrades including a new association database (association management system [AMS]), which influences the pace and direction of making changes to website. APSA is committed to adjusting the homepage without obstructing current search for a new AMS system and other structural questions. He introduced Polly Karpowicz, Director of Communications and Publishing, to present the plan.

Polly Karpowicz presented the plan to restructure the APSA homepage and informed the council about the immediate changes that are being undertaken, as Phase I. The method of the immediate update is described as a restructuring of the skin (or homepage), so that immediate changes can be made without waiting for larger system changes needed to alter the structure of other content. Phase II is the redevelopment of everything else (AMS, CMS, and other related web applications). This phase could take between 18 and 24 months to complete and may involve a usability study.

President Mansbridge thanked Polly Karpowicz and suggests that the council communicate by e-mail if they have ideas/comments regarding the topic buttons/entry points that will be used on the homepage.
AD HOC COMMITTEE ON WORKABLE SOLUTIONS TO ADVANCE WOMEN

IN THE PROFESSION

The council tabled this report until the August meeting.

\section{JOB APPLICATION PROCESS}

The council discussed the idea of a portfolio management system and asked the Departmental Services Committee to look into the issue and report back in future council meetings.

\section{ADJOURNMENT}

The council adjourned at 4:30 p.m. 